\title{
Feminisme Perempuan Adat Di Pulau Buru
}

Belinda Sam, Lutfi Rumkel, Abdi Wael, Idrus Hentihu, Rosita Umanailo, Hamiru Hamiru, Mansyur Nawawi, Sukainap Pulhehe, Mirja Ohoibor, Riki Bugis, Edi Said Ningkeula SP, Muhammad Bula, Iskandar Hamid, Irma Magfirah, Said Abdurahman Assagaf, Siami Prafitriyani, Abdul Latif Wabula, Wa Malmia, Syaiful Rachman, Salma Yusuf, M Yusran Zakaria

Universitas Iqra Buru

chairulbasrun@gmail.com

\begin{abstract}
Abstrak
Perempuan adat di Pulau Buru meyakini bahwa kepribadian yang mereka miliki merupakan warisan leluhur mereka, Keyakinan ini menjadikan perempuan adat menjalani kehidupan sehari-hari secara disiplin, penuh kerja keras. Ada kepercayaan yang tertanam dalam batin setiap perempuan adat bahwa tugas seorang istri adalah mendampingi suami dalam ruang rumah tangga sekaligus ruang kerja. Penelitian interdisipliner ini menggunakan pendekatan etnografi dalam pengumpulan data. Situs penelitian ini di Kaeyeli, Wasi dan Kubalahin Kabupaten Buru. Data penelitian dikumpulkan dengan teknik wawancara tidak terstruktur dan observasi. Setelah terkumpul, data dianalisis secara etnografis, yakni analisis wawancara etnografis, analisis ranah, mengajukan pertanyaan struktural, analisis taksonomi, mengajukan pertanyaan kontras, analisis komponensial, analisis tema kultural, dan menulis etnografi.
\end{abstract}

Keyword: feminisme, perempuan, adat, pulau buru

Pulau Buru mempunyai luas sekitar $7.595,13 \mathrm{~km}^{2}$, penduduk Kabupaten Buru berdasarkan data dinas kependudukan dan catatan sipil pada tahun 2017 sebanyak 132.100 jiwa yang terdiri atas 67.815 jiwa penduduk laki-laki dan 64.285 jiwa penduduk perempuan (BPS, 2018). Dari jumlah itu dijumpai hanya sekitar $10 \%$ adalah populasi masyarakat asli (orang Bupolo). Bupolo adalah nama awal pulau Buru, disebut pula Bupolo Waekolo. Waekolo adalah nama kelompok kekerabatan (noro atau soa) yang menyatakan diri sebagai penunggu atau Geba eptugu (geba=orang, eptugu=penunggu) di pusat pulau. Berdasarkan pengakuan adat, pusat pulau Buru dengan Gunung Date dan Danau Rana, adalah milik seluruh orang Bupolo (Pattinama, 2013).

Perempuan merupakan sosok yang sangat luar biasa untuk dibicarakan dan dibahas. Perempuan seringkali dikaitkan dengan keberadaan genre yang menjadi sebuah daya tarik sendiri untuk diceritakan dari banyak hal, termasuk perempuan sebagai manusia dengan hak-haknya. Banyak kajian di Indonesia memandang peran perempuan menjadi dua bagian kategori. Kategori pertama adalah peran perempuan dilihat dari segi biologisnya sebagai istri, ibu, dan anak atau berdasarkan tradisi lingkungan. Kedua, bahwa perempuan berkedudukan sebagai makhluk individu dan makhluk sosial bukan sebagai pendamping suami (Safitri, 2014).

Perjuangan perempuan untuk mewujudkan persamaan hak dengan laki-laki dengan cara mengembangkan kemampuansecara optimal selaras dengan prinsip perjuangan feminis. Kelemahan dan kebodohan kaum perempuan bukan karena kodrat melainkan karena tidak dibiasakan dan tidak diberi kesempatan yang sama dengan kaum laki-laki, namun perbedaan yang jelas antara konsep jenis kelamin telah melahirkan ketidakadilan baik kaum laki-laki, terutama perempuan. Disadari atau tidak, ketika gagasan feminis ini dilihat secara sekilas, 
sepertinya perempuan yang menjadi korban konsep-konsep genre tersebut. Sikap laki-laki yang kontras feminis terlihat dari tingkah laku mereka yang tidak menghargai perempuan, bahkan cenderung semena-mena.

Perempuan adat di Pulau Buru meyakini bahwa kepribadian yang mereka miliki merupakan warisan leluhur mereka, Keyakinan ini menjadikan perempuan adat menjalani kehidupan sehari-hari secara disiplin, penuh kerja keras. Ada kepercayaan yang tertanam dalam batin setiap perempuan adat bahwa tugas seorang istri adalah mendampingi suami dalam ruang rumah tangga sekaligus ruang kerja. Penelitian interdisipliner ini menggunakan pendekatan etnografi dalam pengumpulan data. Situs penelitian ini di Kaeyeli, Wasi dan Kubalahin Kabupaten Buru. Data penelitian dikumpulkan dengan teknik wawancara tidak terstruktur dan observasi. Setelah terkumpul, data dianalisis secara etnografis, yakni analisis wawancara etnografis, analisis ranah, mengajukan pertanyaan struktural, analisis taksonomi, mengajukan pertanyaan kontras, analisis komponensial, analisis tema kultural, dan menulis etnografi.

Zainal (2016) dalam penelitiannya tentang bias potret perempuan muna menemukan bias gender dalam potret perempuan dikuatkan lewat tradisi yang mengatur dan mengontrol gambaran perempuan ideal. ada tiga rangkaian ritual life-cycle perempuan dalam masyarakat Muna di Sulawesi Tenggara yang disebut dengan kangkilo, katoba, dan karia (3K). Pubertas laki-laki dalam masyarakat Muna lebih bersifat biologis, sementara pubertas perempuan bersifat biologis sekaligus sosial. Dengan perspektif antropologi feminis menegaskan bahwa tiga rangkaian ritual perempuan dalam masyarakat Muna menunjukan upaya budaya dalam membentuk karakter perempuan ideal pada sisi reproduksinya, yang justru menegaskan bias perlakukan oleh sebab ketiadaan ritual produksi bagi laki-laki dalam ritual life cycle-nya. Temuan ini meggarisbawahi bahwa potret perempuan dalam tradisi seringkali bersifat paradoks dan tidak fair, dimana pubertas perempuan bersifat sosial dan dikonstruk secara kultur, sementara pubertas laki-laki bersifat biologis.

Indraswari (2009) dalam kanjiannya tentang perempuan dan kemiskinan menyajikan data kuantitatif di tingkat makro dan data kualitatif di tingkat mikro mendukung pernyataan bahwasanya di kalangan orang miskin perempuan adalah kelompok termiskin dan mencerminkan kuatnya budaya patriarki yang menomorduakan perempuan ketimpangan gender memperparah kemiskinan perempuan dan sebaliknya kemiskinan itu sendiri berkontribusi terhadap semakin tajamnya ketimpangan gender.

Penelitian ini dilakukan berdasarkan preferensi pendekatan etnografi tentang feminism perempuan. Penelitian ini untuk untuk melihat adanya suatu pola konstruktif pemikiran masyarakat terhadap perempuan adat di Pulau Buru, sehingga dapat diharapkan adanya deskripsi khusus tentang keberadaan perempuan adat dalam kehidupan bermasyarakat.

Diawali dari pemahaman-pemahaman tertentu terhadap perbedaan biologis antara laki-laki dan perempuan yang terisosialisasi dalam waktu yang cukup panjang, bermuara pada terbentuknya sistem nilai. Sistem nilai yang menjadi pola, tuntutan, bahkan mengikat masyarakat dalam bersikap pada proses sosialnya. Sistem nilai yang membentuk kultur tertentu dalam memposisikan dan memberi peran pada perempuan dalam pergaulan hidup bermasyarakat.

Pada prinsipnya, adanya perbedaan biologis antara laki-laki dan perempuan, sesungguhnya tidaklah menjadi masalah dan oleh karena itu tidak perlu dipermasalahkan. Secara kodrati kaum perempuan dengan organ reproduksinya bisa hamil, melahirkan dan menyusui, dan kemudian memiliki peran gender sebagai perawat, pengasuh, dan pendidik adalah hal yang alamiah Persoalannya adalah ternyata peran gender perempuan dinilai dan dihargai jauh lebih rendah dibanding peran gender laki-laki. Peran gender ternyata melahirkan ketidakadilan, pendiskriminasian dan penindasan terhadap kaum perempuan. Hal ini pada dasarnya adalah sebuah konstruksi sosial budaya yang dibangun oleh komunitas tertentu. 
Ketertindasan perempuan, secara antropologis, dipandang oleh Sherry Ortner (dalam Moore, 1998:30) disebabkan oleh sebuah sistem nilai yang diberikan makna tertentu secara kultural. Ortner menempatkan ketertinggalan perempuan pada tataran ideologi dan simbol kebudayaan. Dalam budaya universal, ketertindasan perempuan, menurut Ortner merupakan manivestasi dari pemahaman antara budaya dan alam yang kemudian dibandingkan dengan posisi laki-laki dan perempuan pada peran sosialnya. Secara umum, kebudayaan memberikan pembedaan antara masyarakat manusia dan alam. Kebudayaan berupaya mengendalikan dan menguasai alam yang selanjutnya dimanfaatkan untuk berbagai kepentingan. Oleh sebab itu kebudayaan berada pada posisi superior dan alam dipihak inferior. Kebudayaan diciptakan untuk menguasai, mengelola dan mengendalikan alam untuk mempertahankan kelangsungan kehidupan masyarakat. Dalam hubungannya dengan laki-laki dan perempuan, maka perempuan selalu diasosiasikan dengan alam, dan laki-laki diasosiasikan dengan kebudayaan. Oleh karenanya merupakan suatu hal yang alami jika perempuan berada pada posisi yang dikontrol, dikendalikan dan dikuasai. Konsep ini ada kesamaan dengan konsep orang Turki tentang perempuan, bahwa perempuan diasosiasikan dengan tanah dan laki-laki diasosiasikan dengan benih (padi) sebagai pemahaman atas reproduksi.

Sebuah definisi umum yang dikemukakan Sarah Gamble dalam bukunya "Feminisme dan Post-feminisme" (Gamble, 2010: 1), menyebutkan bahwa feminisme merupakan sebuah kepercayaan dimana perempuan -sematamata karena mereka adalah perempuan- diperlakukan tidak adil dalam masyarakat yang dibentuk untuk memprioritaskan cara pandang laki-laki serta kepentingannya. Dalam pola patriarkal, perempuan menjadi semua hal yang bukan laki-laki (atau citra yang tidak diinginkan laki-laki); dimana laki-laki dianggap kuat, perempuan lemah; laki-laki dianggap lebih rasional dan perempuan emosional; laki-laki dianggap lebih aktif, perempuan pasif; dan sebagainya.

Perempuan diartikan dalam definisi yang dikemukakan Gamble sebagai makhluk kelasdua dan bersifat inferior. Artinya perempuan masih berada satu tingkat di bawah laki-laki. Akibat budaya yang dibentuk oleh kaum laki-laki, seluruh identitas perempuan seperti emosional, mengutamakan perasaan, serta tidak mampu bekerja kasar, dianggap sebagai sifat-sifat yang keliru dan pantang oleh laki-laki dianut (Adiwilaga, 2017).

Lebih jauh lagi, kaum feminisme mengaggap bahwa seseorang tidak lahir sebagai seorang wanita atau laki-laki tetapi mereka ada atas konstruksi sosial masyarakat. Reaksi feminisme kemudian adalah dengan membuat teori yang lebih menguntungkan posisinya. Teori feminis tersebut adalah sistem ide yang digeneralisasi, meliputi banyak hal tentang kehidupan sosial dan pengalaman manusia yang dikembangkan dari suatu perspektif yang berpusat pada wanita di dalam dua cara: (1) Titik tolak semua penyelidikan adalah situasi-situasi dan pengalamanpengalaman wanita di dalam masyarakat dan (2) teori tersebut berusaha melukiskan sosial dari posisi khas yang menguntungkan wanita (Syahrul, 2017).

\section{Referensi}

Adiwilaga, Rendy. 2017. Feminisme Dan Ketahanan Budaya Perempuan Indonesia Dalam Perspektif Organisasi Islam Wanita. Jurnal Polinter Prodi IImu Politik FISIP UTA'45 Jakarta, 2 (2).

BPS. 2018. Kabupaten Buru Dalam Angka. Publication Number: 81040.1804.

Ernawati. 2014. Perempuan Dan Kearifan Lokal: Performativitas Perempuan Dalam Ritual Adat Sunda. Musâwa, 13 (2).

Hamid, I. (2010). Identifikasi gulma pada areal pertanaman cengkeh Eugenia aromatica) di Desa Nalbessy Kecamatan Leksula Kabupaten Buru Selatan. Agrikan: Jurnal Agribisnis Perikanan, 3(1), 62-71.

Hentihu, Idrus (2007) Analisisi Pemasaran Tanaman Nilam (Pogostemon cablin Benth)( Studi Kasus Desa Pamotan Kecamatan Dampit Kabupaten Malang ). Other thesis, University of Muhammadiyah Malang. diakses tanggal 15 Agustus 2018.

Indraswari. 2009. Perempuan dan Kemiskinan. Jurnal Analisis Sosial, 14 (2); 40-52.

Magfirah, I. (2017). Efektivitas Model Pembelajaran Discovery dengan Setting Kooperatif Ditinjau dari Kemampuan Analogi dan Generalisasi Matematis Siswa Kelas VII MTs Al-Fakhriyah Makassar (Doctoral dissertation, Universitas Negeri Makassar). 
Magfirah, I., Rahman, U., \& Sulasteri, S. (2015). Pengaruh Konsep Diri Dan Kebiasaan Belajar Terhadap Hasil Belajar Matematika Siswa Kelas Viii Smp Negeri 6 Bontomatene Kepulauan Selayar. MaPan: Jurnal Matematika dan Pembelajaran, 3(1), 103116.

Nawawi, M., \& Agus Sudaryanto, S. H. (2009). Perkawinan adat sasi dan akibatnya terhadap hukum kekerabatan adat di Desa Debowae Kecamatan Waeapo Kabupaten Buru (Doctoral dissertation, Universitas Gadjah Mada).

Ningkeula, E. S. (2015). Analisis karakteristik metereologi dan morfologis DAS Wai Samal Kecamatan Seram Utara Timur Kobi Kabupaten Maluku Tengah. Agrikan: Jurnal Agribisnis Perikanan, 8(2), 81-91.

Ningkeula, E. S. (2016). Analisis karakteristik morfometri dan hidrologi sebagai ciri karakteristik biogeofisik DAS Wai Samal Kecamatan Seram Utara Timur Kobi Kabupaten Maluku Tengah. Agrikan: Jurnal Agribisnis Perikanan, 9(2), 76-86.

Pattinama, Marcus J. 2013. Potret Perempuan Buru Dan Tanggung Jawab Sosial Perusahaan Eksploitasi Hutan Di Pulau Buru, Maluku. PIRAC (Public Interest Research And Advocacy Center). http://maxmjpattinama.unpatti.org diakses tanggal 15 Agustus 2018.

Pulhehe, S. (2001). Tinjauan PP Nomor 10 Tahun 1983 Menurut Hukum Islam (Perkawinan-Perceraian) (Doctoral dissertation, Universitas Airlangga).

Putri, Perdana. 2016. Quest for Feminist Technology: Challenges to 21st Feminism. Jurnal Perempuan, 21 (4); 395-403.

Safitri, Mentari Asih Lina Ayu. 2014. Kajian Feminisme Terhadap Novel Perawan Remaja Dalam Cengkeraman Militer Karya Pramoedya Ananta Toer. https://media.neliti.com diakses tanggal 15 Agustus 2018.

Syahrul. 2017. Dilema Feminis Sebagai Reaksi Maskulin Dalam Tradisi Pernikahan Bugis Makassar. Jurnal Al-Maiyyah, 10 (2).

Umanailo, M Chairul Basrun. (2019). Strategi Bertahan Hidup Petani Padi Gogo Di Pulau Buru Survival Strategies Of The Upland Rice Farmers In Buru Island. Jurnal Ekonomi Pertanian dan Agribisnis, 3 (1);50-58.

Umanailo, M Chairul Basrun. 2017. "Kajian dan Analisis Sosiologi." OSF. December 11. doi:10.17605/OSF.IO/PV24F.

Umanailo, M Chairul Basrun. 2017. “Marginalisasi Buruh Tani Akibat Alih Fungsi Lahan." OSF. December 11. doi:10.17605/OSF.IO/9CZK2.

Umanailo, M Chairul Basrun. 2017. “Masyarakat Buru Dalam Perspektif Kontemporer.” OSF. December 10. doi:10.17605/OSF.IO/KZGX3.

Umanailo, M Chairul Basrun. 2017. “Mengurai Kemiskinan Di Kabupaten Buru." OSF. November 4. doi:10.17605/OSF.IO/8WDXE.

Umanailo, M Chairul Basrun. 2018. "Ilmu Sosial Budaya Dasar." OSF. March 17. doi:10.17605/OSF.IO/4HPWC.

Umanailo, Rosita (2009) Studi Tentang Struktur Dan Komposisi Hutan Pantai Sendang Biru Malang Selatan. Other Thesis, University Of Muhammadiyah Malang. http://eprints.umm.ac.id/11153/ diakses tanggal 15 Agustus 2018.

Umanailo, Rosita (2013) Implementasi Kebijakan Perum Perhutani Dalam Pengelolaan Sumberdaya Hutan Bersama Masyarakat Sekitar Hutan (Studi Di Wilayah Perum Perhutani Kph Malang). Masters thesis, University of Muhammadiyah Malang. http://eprints.umm.ac.id/30546/ diakses tanggal 15 Agustus 2018.

Zainal, Asliah. 2016. Bias Potret Perempuan Muna Dalam Ritual LIFE-CYCLE. International Conference on Feminism: Intersecting Identities, Agency \& Politics (20 Years Jurnal Perempuan). https://www.jurnalperempuan.org diakses tanggal 15 Agustus 2018.

Zakaria, M. Y. (2017). Karakteristik Penyelesaian Masalah Matematika ditinjau dari Kecenderungan Kepribadian Pada Siswa kelas X SMA Negeri 16 Makassar (Doctoral dissertation, Pascasarjana). 